\title{
BUILDING RELATIONSHIPS FOR CRITICAL SERVICE-LEARNING
}

Debra A. Harkins, Lauren I. Grenier, Cynthia Irizarry, Elizabeth Robinson, Sukanya Ray, and Lynne-Marie Shea

\section{Abstract}

Service-learning is a pedagogical approach that higher education can use to promote civic engagement among students, but it has not fully realized its original civic purpose. Butin (2010) argues that to meet its civic mission, service-learning must move toward a more justice-oriented pedagogy that empowers stakeholders to bring about social change. To that end, we worked toward a more critical model of service-learning, first proposed by Mitchell (2008), that encourages a social change approach to service-learning. We propose that students' relationships with their professors, community partners, and peer mentors help facilitate this goal. We examined how these three types of relationship impacted students' civic engagement. Results demonstrated that each type of relationship had a different impact on students' developing civic engagement attitudes. This article discusses how such relationships can help achieve critical service-learning's goal of developing more participatory and transformational citizens.

Service-learning represents an important pedagogical approach that higher education can use to promote civic engagement among students (Duncan \& Kopperud, 2008). Civic engagement, defined by Thomas Ehrlich (2000), is using political and non-political means to engage with a community to make a positive difference in the quality of life for members of that community. Higher education is uniquely positioned to encourage civic engagement because it can provide students with a space to recognize injustice and inequality, to obtain skills to speak and act on unchallenged systems, and to gain intercultural competencies to promote public action (Musil, 2009). We propose that service-learning students' relationships with their professors, community partners, and peer mentors further develop their civic engagement attitudes.

Research demonstrates a wide range of benefits of service-learning for students including significant gains in social skills, academic performance, personal insight, and cognitive development (Celio et al., 2011; Yorio \& Feifei, 2012). These benefits in student outcomes reveal the positive impact of service-learning coursework on students' personal and professional development (Butin, 2010). Such glowing findings might mislead us into thinking service-learning has only positive outcomes. A significant number of theorists and researchers have 
cautioned that the potential for service-learning to create transformative change may instead represent only ameliorative change that unintentionally reinforces or even strengthens power imbalances (Boyle-Baise, 1999; Cross, 2005; Himley, 2004; Hullender et al., 2015; Rosenberg, 1997; Sleeter, 2001; Varlotta, 1997).

Critical service-learning pedagogy addresses these concerns and aims to promote social justice by educating students on how to deconstruct theoretically, empirically, and practically the power structures that underlie many traditional views of the world (Campus Compact, 2000). A specific focus of critical service-learning pedagogy is on the power dynamics that exist between those with the power and privilege to help and the recipients of that help, who often have far less power and privilege. This transformative learning requires a shift from taking for granted assumptions about how the world works to a more critical stance, questioning one's assumptions while seeking more inclusive and reflective thoughts that can guide one toward more socially just action (Baxter Magolda \& Boes, 2017; Brukardt et al., 2004; Butin, 2010; Campus Compact, 2000; Kegan, 2000; Mitchell, 2008; O’Meara \& Niehaus, 2009; Saltmarsh \& Harley, 2008; Varlotta, 1997).

Critical service-learning is a model that adopts a social justice framework, as opposed to a more "apolitical helper” model of service-learning, and demands an analysis of power structures and social change (Mitchell, 2008; O’Meara \& Niehaus, 2009; Rice \& Pollack, 2000; Rosenberger, 2000). A critical model of service-learning includes: (a) providing a social change orientation; (b) working to redistribute power; and (c) developing authentic relationships. Mitchell (2008) states that these authentic relationships challenge the self-other binary, emphasizing interdependence and reciprocity, and demand an analysis of both power structures and social change. A major focus of this study is to understand how service-learning students' relationships facilitate critical servicelearning, specifically when it comes to the students' civic engagement attitudes. We explored the relationships between the students and their teachers, their community partners, and their peer mentors.

Researchers find extensive evidence that relationships often occur through formalized mentoring (Fassinger, 1997; Hay, 1995). Within higher education specifically, peer mentoring of undergraduate students increases their sense of belonging, competence, identity, professional development, academic learning, and social responsibility (Bernier et al., 2005; Campbell et al., 2012; Parks, 2000; Pascarella \& Terenzini, 2005). We define service-learning mentoring as a relationally focused process that supports students' professional, social, and civic development through reflection on what it means to help, the role of power in helping, and how personal values influence helping (Harkins, 2017). While there is substantial literature supporting mentoring models (DuBois et al., 2011; Lunsford et al., 2017), integrating peer-mentoring into a service-learning classroom is not common practice. We found only one study that examined peer-mentoring for service-learning students (Haddock et al., 2013), and the focus was on the mentors (college students) rather than the mentees (exclusively at-risk college students).

For the current study, we explored the impact of three relationships on service-learning students' civic attitudes, including civic knowledge, skills, values, behaviors, and identity (Ehrlich, 2000; Hemer \& Reason, 2017; Torney-Purta et al., 2015). Service sites included an after-school tutoring and mentoring program, an urban debate league, and work with an advocacy homelessness organization. A unique component of this study was exploring service-learning peer mentoring. Peer mentoring included undergraduate students with experience in service-learning, known as service-learning assistant mentors (SLAMs), mentoring service-learners as they 
worked with a community partner. Based on findings from Robinson and Harkins (2018) regarding components of successful faculty mentoring relationships, faculty helped SLAMs to build an alliance with students through support and motivation. We expected that not only would building relationships with the professor and community partner increase civic engagement attitudes for service-learners but also students receiving peer mentoring would have attitudes reflected a stronger sense of civic engagement than service-learners who received no peer mentoring. We predicted associations between relationship quality with SLAMs, professor, and community partners and our outcome variable of civic engagement attitudes.

\section{Method}

\section{Participants}

Participants consisted of 125 undergraduate students from a mid-sized, urban university in the U.S. Northeast. Of this sample, 86 participants (68.8\%) identified as female, 63.2\% identified as White or Caucasian, 15.2\% identified as Latino/a or Hispanic, $10.4 \%$ identified as two or more ethnicities, 5.6\% identified as Black or African American, .8\% identified as Asian, and $2.4 \%$ identified as "other" or did not identify their race/ethnicity. The mean age was 21.04 years old $(S D=1.88)$ with a range of $18-28$ years old.

We recruited participants through enrollment in 10 service-learning focused courses during the 2017-2018 academic year. Course structure determined two service-learning groups: mentored groups (MG) and non-mentored groups (NMG) who engaged in service as a component to their course. Students in the MG $(n=60)$ received mentoring support from an undergraduate peer mentor who had recently completed a service-learning course (identified hereafter as a SLAM), whereas the NMG $(n=65)$ did not receive mentoring support from a SLAM. All 10 courses belonged to the university's College of Arts and Sciences (CAS) and included psychology, education, communication, English, and art and design. Eighty-three percent of professors identified as female, and all possessed a $\mathrm{PhD}$. Community partners included local public schools, a debate team, and a homeless nonprofit organization.

\section{Service-Learning Assistant Mentors}

Service-learning assistant mentors (SLAMs) were undergraduate students with prior experience in servicelearning. SLAMs served as peer mentors to undergraduate students enrolled in a service-learning course and as liaisons between faculty members and undergraduate students. SLAMs operated differently depending on their course assignment: SLAMs either met one-on-one with students to individually mentor them in their experience or conducted group mentoring through guided reflections during structured class time. SLAMs worked closely with the professor of their assigned course in structuring in-class critical reflection activities and mentoring undergraduate students enrolled in the service-learning course. SLAMs applied for the position and were matched with a service-learning course based on their completion of an interest and skills survey. All SLAMs were recruited through previous enrollment in service-learning courses at the university. 


\section{Materials and Procedure}

The Civic Attitudes and Skills Questionnaire (CASQ) (Moely, McFarland et al., 2002), a 44-item self-report measure, assesses skills, attitudes, and action plans related to civic engagement and produces six subscales: civic action, interpersonal and problem-solving skills, political awareness, leadership skills, social justice attitudes, and diversity attitudes. Moely, Mercer et al. (2002) demonstrated validity with two samples of undergraduate students $(N=761,725)$ with internal consistency of all subscales ranging from .69 to .88 and test-retest scores within a three-month period of .70 or higher for five of the six subscales. The CASQ was chosen as our civic engagement measure due to its inclusion of the more critical-oriented scales of civic action, political awareness, social justice attitudes, and diversity attitudes, which target sociopolitical outcomes that critical service-learning seeks to attain. For this article, we chose to only examine civic action, political awareness, social justice attitudes, and diversity attitudes due to the critical-oriented focus of these subscales. These subscales focus on how relationships relate to critical service-learning outcomes, such as a commitment to civic engagement (civic action and political awareness); understanding of power dynamics (political awareness, diversity attitudes); and orientation toward social change (social justice attitudes).

The Network of Relationships Inventory-Social Provisions Version (NRI-SPV) (Furman \& Buhrmester, 1985), a 36-item self-report instrument, measures perceptions of relationships based on social needs, provisions, and negative interactions (Sullivan, 1953; Weiss, 1974). It produces 10 scales-companionship, conflict, instrumental aid, antagonism, intimate disclosure, nurturance, affection, reassurance of worth, relative power, and reliable alliance - and two supplemental scales, punishment and satisfaction. The NRI-SPV is the most widely used of the three versions of the Network of Relationships Inventory (NRI). Reliability supported this measure with all scales over .60 except for two instances and is flexible in assessing different relationships, as scales can be removed if they do not appropriately assess the relationship in question (Furman \& Buhrmester, 1985). Six of the original scales-conflict, instrumental aid, antagonism, intimate disclosure, reassurance of worth, nurturance - and one supplemental scale, satisfaction, were utilized in this study and were easily generalizable to the mentoring relationships found in this study. Companionship, reliable alliance, affection, and punishment were not included in this study because they did not generalize to mentoring relationships. For example, sample items from companionship included "How often do you spend fun time with this person?" In total, we asked participants 27 questions in the context of three relationships the student experienced throughout their service: with their professor, their SLAM, and a member of the community partner or service site.

At the beginning of the fall 2017 and spring 2018 semesters, all participants completed a pretest of the CASQ. Throughout the semester, students from all groups engaged in service at their respective sites. Students with a SLAM received mentoring support throughout the semester. SLAMs also met with the professor of their course intermittently throughout the semester. At the conclusion of each semester, all participants completed a posttest assessment of the CASQ. The MG completed the NRI-SPV. 


\section{Focus Groups}

While we expected the surveys to reveal a correlation between civic attitudes and mentoring, we conducted focus groups to gain a deeper understanding of how this connection developed within the mentoring relationship. At the conclusion of two semesters, we conducted seven one-hour focus groups (8-10 students per group) with students from the MG to explore participants' attitudes and feelings toward service-learning and SLAMs. The primary focus group questions were developed largely from the factors in the CASQ surveys. Two moderators were trained to conduct focus groups. Both moderators were psychology doctoral students who conducted semi-structured interviews with participants using open-ended questions with initial pre-planned probes from the moderator guide.

Focus groups were video recorded and transcribed using Dragon NaturallySpeaking speech recognition software with human edit checks by the moderators, leading to 110 pages of transcripts. A three-person coding team consisted of two graduate students (Grenier, Shea) and a professor (Irizarry). When coding the focus group transcripts, conventional content analytic guidelines were used to create operational definitions of all categories used. Coders were trained in the use of these categories and performed frequent reliability checks to ensure that all data were coded in similar ways. After creating a preliminary codebook, the team validated the codebook through blind coding of $20 \%$ of the data and repeated meetings to engage in negotiated agreement (Campbell et al., 2013). The codebook was validated after reaching Cohen's kappa of .80 (Syed \& Nelson, 2015). According to Landis and Koch (1977), kappa values greater than .75 indicate good agreement beyond chance. One member of the team coded the rest of the data using MAXQDA, software for a mixed methods analysis.

While exploratory in nature, we expected associations between relationship type and civic engagement attitudes in surveys. Specifically, we expected a positive association between civic engagement and social support relationship qualities with SLAMs, professors, and community partners, and we expected an inverse association between civic engagement and negative interaction relationship quality. We also expected that students who were peer mentored would have attitudes that reflected stronger sense of civic engagement attitudes than students who were not peer mentored. Focus group results were examined to determine whether themes of civic engagement and relationship emerged. Taken together, we expected the surveys and focus groups to provide support for the benefit of a mentoring relationship on a service-learning student's civic development.

\section{Results}

\section{Relationships and Civic Engagement}

To explore the role of relationships on student civic engagement attitudes, we examined students' perceptions of their relationships (SLAM, professor, and community partner) and civic engagement outcomes. We found support for positive correlations between social support and civic engagement outcomes. 


\section{Service-Learning Peer Mentoring and Civic Engagement}

To assess if peer mentoring had an impact on civic engagement outcomes, we conducted a multivariate analysis of variance (MANOVA) with scores from the CASQ. First, we assessed if there were any significant differences in pretest scores among our two groups and as expected found none. Next, we examined posttest scores and found a significant difference for civic action, $F(1)=4.51, p=.037$, such that students with a SLAM had higher posttest civic action scores $(M=4.20, S D=.52)$ than students who received no mentoring support $(M=3.93$, $S D=.62$ ). We also found a trend for social justice attitudes, $F(1),=2.80, p=.098$, such that students who received mentoring from a SLAM had higher posttest social justice attitudes $(M=4.06, S D=.54)$ than did students who received no mentoring support $(M=3.84, S D=.60)$.

\section{Exploring Relationships}

\section{SLAM-Student Relationship}

To assess if civic engagement variables and student-SLAM relationships were correlated, we conducted correlational analyses of the CASQ and the NRI. A positive relationship was found between the students' CASQ variable civic action and SLAM-student relationship variables. Specifically, there was a correlation between civic action and the NRI relationship variables guidance $(r=.32, p<.05)$; satisfaction $(r=.33, p<.01)$; nurturance $(r$ $=.45, p<.01)$; reassurance of competence $(r=.48, p<.01)$; and intimate disclosure $(r=.31, p<.05)$. See Table 1 for results.

Table 1

Correlations for Scores on NRI-SPV and CASQ for Relationship With SLAM

\begin{tabular}{|c|c|c|c|c|c|}
\hline NRI-SPV & Aid & Satisfaction & Nurturance & Worth & Disclosure \\
\hline \multicolumn{6}{|l|}{ CASQ } \\
\hline Civic action & $.32^{*}$ & $.33^{*}$ & $.45^{* *}$ & $.48^{* *}$ & $.31^{*}$ \\
\hline
\end{tabular}

Note. ${ }^{*} p<.05,{ }^{* *} p<.01$.

Focus group findings both illuminated and aligned closely with the survey data themes of guidance, nurturance, satisfaction, and intimate disclosure. Service-learning students frequently reflected on how valuable they found the SLAM-student mentoring relationship. For example, many students voiced common expressions of guidance about their SLAM, as one student commented:

It [having a SLAM] allows each person to have more time to talk about their experience and issues they're having, it's more individual for the entire class - it gives everyone a space to talk about that stuff. And $[\mathrm{SLAM}]$ is great at leading the discussion. 
Guidance included providing more opportunities and spaces for students to interact with a peer mentor. Similarly, another student noted how guidance received from a SLAM helped to positively frame the student's service-learner experience: "I also feel like having other people who have gone through this and had a positive experience really helped me to like, think of the 'positives."'

Nurturance was another common theme found in the surveys and focus groups. The following student example illustrates the frequently expressed feelings by many students for their SLAMs and how this support nurtured both the mental and emotional work of students engaged in service-learning:

And then the last class she met with us individually for a few minutes just to check in and see how we're doing mentally and emotionally but also with the site and things like that which was actually really helpful.

Satisfaction was the third common theme found in the surveys and reiterated in the focus groups. The following reflection reflects a typical response regarding the value of having both the SLAM and professor perspectives:

The position I think is great, it's great to have her in the class-her position as a SLAM member in this class-because we get a student perspective and teacher perspective ... that's what I definitely like, like if I see something that [Professor] says, but then [SLAM] will bring something up from the student perspective, because she's kind of like our level so there's different connections.

As the themes of guidance, nurturance, satisfaction, and intimate disclosure are all closely related, it was common for students to include several of these themes in their reflections on their relationship with the SLAMs. For example, another student describes her satisfaction with the opportunity the SLAM provided for intimate disclosure as an alternative pathway to discuss issues that the student may not want to address with the professor:

So, it was just a really good pathway to open up about it but then also, she would ask if there were any issues or anything so then we could tell them about it rather than, you don't have to tell the professor about it.

These quotes shed light on students' experiences of having a SLAM in their service-learning course. Students valued a peer's point of view, felt comfortable opening up to a peer on certain issues, and appreciated the emotional support a SLAM provided.

\section{Professor-Student Relationship}

We found a high number of correlations between students' civic engagement attitudes and mentoring relationships between students and professors. Positive correlations were found between the CASQ variable civic action and the NRI professor relationship variables guidance $(r=.39$, $p<.05)$; satisfaction $(r=.46, p<.001)$; nurturance $(r=.28, p<.05)$; reassurance of competence $(r=.41, p<.01)$; and feelings of power $(r=.38, p<.01)$. We found 
positive correlations for the CASQ variable diversity with the NRI professor relationship variable guidance $(r$ $=.35, p<.01)$. Finally, we found positive relationships between the CASQ variable political awareness and the NRI professor relationship variables guidance $(r=.36, p<.01)$; satisfaction $(r=.37, p<.01)$; reassurance of competence $(r=.24, p<.05)$; and power $(r=.27, p<.05)$.

We found negative correlations between the CASQ variable social justice and the NRI professor relationship variables conflict $(r=-.27, p<.05)$ and antagonism $(r=-.42, p<.001)$. In addition, we found negative correlations between the CASQ variable diversity and the NRI professor relationship variables conflict $(r=-.26, p<.05)$ and antagonism $(r=-.34, p<.01)$. See Table 2 for additional results.

Table 2

Correlations for Scores on NRI-SPV and CASQfor Relationship With Professor

\begin{tabular}{|c|c|c|c|c|c|c|c|}
\hline NRI-SPV & Aid & Satisfaction & Nurturance & Worth & Power & Conflict & Antagonism \\
\hline \multicolumn{8}{|l|}{$\overline{C A S Q}$} \\
\hline Civic action & $.39^{* *}$ & $.46^{* * *}$ & $.28^{*}$ & $.41^{* *}$ & $.38^{* *}$ & -.08 & -.21 \\
\hline IPSS & $.27^{*}$ & $.30^{*}$ & .12 & $.31^{*}$ & .21 & -.00 & -.14 \\
\hline Leadership & .19 & .22 & .05 & $.35^{*}$ & .15 & -.15 & -.16 \\
\hline Social justice & $.27^{*}$ & .21 & -.02 & .28 & $.28^{*}$ & $-.27^{*}$ & $-.42^{* * *}$ \\
\hline Diversity & $.35^{* *}$ & .23 & -.06 & .23 & .23 & $-.26^{*}$ & $-.34^{* *}$ \\
\hline Political awareness & $.36^{* *}$ & $.37^{* *}$ & .17 & $.24^{*}$ & $.27^{*}$ & .06 & -.07 \\
\hline
\end{tabular}

Note. ${ }^{*} p<.05,{ }^{* *} p<.01,{ }^{* * *} p<.001$.

The focus groups provided similar themes of guidance, power, reassurance of competence, and satisfaction, reflecting how valuable service-learning students found strong professor-student relationships were to their professional development. The following student's response demonstrates ways a professor provides guidance through feedback and preparation for the professional world:

We have a great professor. I was given some materials and when I delivered them, the professor gave me just such intensive feedback I was like "wow we're missing so much of this I have to go later to see the professor and fix materials, she gave me such good feedback.”

To a question regarding whether the professor provided space to discuss students' service-learning experiences, the following student's comment reflects a common response received regarding guidance and skill development:

I feel like if we had [professor] for class she actually had topics that we were supposed to be learning and skills we were supposed to be learning, she would be the perfect professor for it she gives such good feedback she's so well-versed in the topics in the subject we got like one-on-one time to just talk to her about it, because we've been so wrapped up in the service aspect.

Similarly, another student describes her satisfaction with the professor and how her relationship with the professor played a role in her service-learning and career path: 
I think it depends on the professor. I think I know [professor] and I wanted to take [my discipline] because I know her, and like the way she teaches and how great she is. I think that plays a factor in my service-learning just as she cares for us and that's why I want to give it back-like okay let's be caring as much for others and for students. I wanted to do a close reading to do service-learning, that's how I began. And [professor] actually gave me a different perspective that kind of made me go into her [discipline]. [Professor] definitely played a big role in my service-learning.

These quotes demonstrate how professors uniquely contribute to student learning, particularly through feedback, experience, and care. Students shared how these qualities in student-professor relationships impacted their perspectives on service-learning.

\section{Community Partner-Student Relationship}

Community partner-student relationship variables with civic engagement outcome variables revealed positive correlations between the CASQ variable civic action and the NRI community partnership relationship variables guidance $(r=.27, p<.01)$; satisfaction $(r=.32, p<.01)$; nurturance $(r=.30, p<.01)$; and reassurance of competence $(r=.27, p<.01)$. We found that conflict between student and community partner negatively correlated with CASQ social justice $(r=-.38, p<.01)$ and diversity $(r=-.36, p<.01)$ attitudes; antagonism between student and community partner also negatively correlated with CASQ social justice $(r=-.41, p<.001)$ and diversity $(r=$ $-.36, p<.01)$ attitudes. See Table 3 for additional correlations.

Table 3 Correlations for Scores on NRI-SPV and CASQ for Relationship with Community Partner

\begin{tabular}{|c|c|c|c|c|c|c|c|}
\hline NRI-SPV & Aid & Satisfaction & Nurturance & Worth & Power & Conflict & Antagonism \\
\hline \multicolumn{8}{|l|}{ CASQ } \\
\hline Civic action & $.27^{* *}$ & $.32^{* *}$ & $.30^{*}$ & $.27^{* *}$ & $.35^{* *}$ & -.12 & -.13 \\
\hline IPSS & .21 & .14 & .22 & $.25^{*}$ & $.29^{* *}$ & -.01 & -.14 \\
\hline Leadership & .08 & .17 & .12 & .13 & .22 & $-.25^{* *}$ & -.20 \\
\hline Social justice & -.04 & .06 & .01 & .12 & .22 & $-.38^{* *}$ & $-.41^{* * *}$ \\
\hline Diversity & .12 & .05 & -.03 & .10 & .20 & $-.36^{* *}$ & $-.39^{* *}$ \\
\hline
\end{tabular}

Note. ${ }^{*} p<.05,{ }^{* *} p<.01,{ }^{* * *} p<.001$.

Similarly, the themes of satisfaction and reassurance of competence often emerged in the focus groups reflecting the value service-learning students found in their relationships with community partners. These relationships most often related to students' professional development. Themes of satisfaction working with a community partner were common as revealed in the following student comment about the different realizations and opportunities that came from her work and relationship with her community partners:

I work with two different nonprofits and one I've been working with this whole school year. And actually, one of the girls that was here also is a volunteer at this nonprofit because it's for middle school-aged girls. 
So, I think it was kind of cool to have been with them and seeing not just middle school girls and this was kind of an extension of seeing how much work needs to be done but also how many different opportunities there are and kind of expanding on it, which was really cool.

The following short but powerful statement from a student reveals the confidence and competence that came from realizing they had the ability to meet the needs of the community partner: "I really stepped it up when the teacher wasn't there.”

In addition, the topic of social justice often emerged in the focus groups as students discussed their understanding of inequalities related to their relationships with the community partners. Several students voiced their emerging understandings of the inequalities school students faced connected to privilege, socioeconomic status, race, ethnicity, and/or language. For example, one student noted, "I actually saw where students from less wealthy, predominantly white-oriented schools were less able to articulate their argument . . . the balance is way off." While students did not quite describe a conflictual or antagonistic relationship with their community partners, some themes suggestive of more apathetic relationships between students and community partners emerged in the focus groups. For example, one student stated the service experience "didn't hit me hard":

If I had a chance to maybe have a relationship with the students I would volunteer again but because I didn't feel like any kind of connection afterwards, besides the fact that I helped, like that felt good, like they need more volunteers, maybe in the future I could come back now that I have experience I could do it. But it didn't hit me hard because I didn't get any connections with the students, but it did motivate me to work with kids in the future perhaps if I was able to work with them on another level.

Another student described looking for a more personal relationship with those served: "I feel like I would definitely continue service but maybe not at (community partner), not because I didn't like it but just kind of to have more of a personal relationship with the people.”

The issue of community partner conflict as examined more closely from the focus groups related more to the logistics of students' scheduling, transportation, and other requirements involved in the service experience rather than any direct conflict with the community partner. For example, one student described her frustration with the commute to her service site: "What I haven't really enjoyed is the commute to the locations. The commute from where I live to [the service site] is tough.”

\section{Discussion}

Our findings support associations between building relationships and students' post-service-learning civic attitudes. Specifically, we found that service-learners who felt positively about their relationships with their professors, community partners, and peer mentors reported more intention to be civically engaged in the future, including plans to engage in more volunteer work, to participate in community action programs and services, 
to help others in need, to make a positive difference, and to help clean up the environment. Students described this change in attitude as a shift in their understanding of their own goals and interests. One student noted, "I am really leaning towards research so it's giving me insight into researching educational inequities.” Another student commented on feelings of connectedness and commitment to the community partner: "I really enjoy being a server. I may continue afterwards a little bit. I don't want to just stop going, and the kids will be like 'what happened to [student]?’”

Additionally, we found that service-learners who had positive service-learning relationships with their professors and community partners reported more social justice-focused attitudes, including understanding the roots of social injustice, the need for public policy change, the need to change people's attitudes, and the need for more equality in society. In focus groups, students reflected on how witnessing inequality at an individual level led to consideration of larger systemic concerns:

I had a Somali kid in my [debate] and he just looked like he had no idea what was going on, and he had his head down and I could tell that when you feel like you can't partake in something you just lose complete interest in it you just try to disassociate yourself from the whole situation and that's what he was doing. ... I would recommend these kids, sons and daughters of immigrants, they need more support, they need much, much more support going into these things, and just in general the language difference, the language barrier, it's really holding them back they don't feel confident the way they don't feel comfortable.

Relationships built at the service sites also led students to reflect on the ways that they saw themselves in those with whom they were working:

I took [the student] to the side and I was like "you need to speak up, you just need to be a confident you" I kind of made sure that [I said] "hey I am also from Egypt which is in Africa as well, look at me here I am standing speaking confidently" and I kind of wanted to be a good example for him.

Service-learning activities, though, are not always considered within a social justice-oriented framework; many view this type of service-learning as too time consuming and resource intensive (Harkins et al., 2018). Professors worry that prioritizing critical service-learning will interfere with more "relevant" course learning and will, in turn, have negative effects on tenure or promotion (Cooper, 2014). This reluctance to dedicate classroom time to reflecting critically on conducting service and making intentional and meaningful connections between these experiences and classroom content seems to be reflected in some of the frustrations expressed by students searching to connect the two course components:

I didn't really view this as a service component because it's a requirement for a class which kind of contradicts the purpose of the service project to me anyway because that's not something I value when I want to do service. 
Service-learning is a pedagogy integrating academic learning and community service. Providing institutional community support in the form of peer mentoring may provide models for students' theoretical and experiential sociopolitical understanding, awareness, and advocacy. Additionally, it provides the relational support needed for professors to feel less encumbered and more willing to engage in critical service-learning. In this way, SLAMs have the potential to serve as a bridge between service experiences and students' personal interests and experiences in the classroom.

The challenging nature of working in community settings with diverse populations and complex needs seems to be reflected in the negative correlations we found between conflict and antagonism felt by the students in their community partner relationships and their expressed civic attitudes about social justice and diversity. It seems that as students move outside traditional classroom settings, with well-defined power structures and metrics for success, experiences of conflict or misalignment in work with community partners may lead them to question their own competence or commitment to social justice and diversity. The power of the SLAM-student relationship, then, lies in the demonstrated correlation between feelings of guidance, nurturance, and reassurance of competence and increases in students reported civic attitudes. The biggest impact of the SLAM-student relationship was on a service-learner's intention to be more civically engaged in the future, suggesting that SLAMs served not only as role models of continued civic engagement for service-learners but also as guides for making meaning of the kinds of challenging community experiences that called service-learners' social justice attitudes into question. SLAMs worked with students throughout the semester both to validate these experiences for their peers and as examples of having found the kind of meaning and purpose in community work that allows for sustained engagement.

The role of SLAMs as models and facilitators of meaning-making is further supported by our findings that peer mentoring enacted deeper relationships between the student and SLAM through increased levels of intimate disclosure. While students reported that relationships with faculty also led to increased intention to be more civically engaged in the future and in reported political, diversity, and social justice awareness, studentperceived conflict and antagonism with their professor led to decreased reports of diversity and social justice awareness. Students' civic engagement attitudes can thus be influenced in either direction by relationships with their course professor. These findings suggest a need for more resources and smaller class sizes to support peermentoring to ensure both students and professors establish and maintain the relationships needed to facilitate positive outcomes in the classroom and beyond. Moreover, the relationships between intimate disclosure and civic engagement support past research showing students' level of intimate disclosure with professors declines during a student's development (Wu \& Hughes, 2015). We interpret these findings as reflective of the power dynamics between students and their professors and the perception of authority that faculty members hold. This supports the need for peer mentors in the service-learning classroom where service-learners can connect with peers who may be more relatable, particularly when students experience distress or a sense of conflict or inadequacy in their community settings.

Nurturing such critical interpersonal relationships will require more intensive time for students and professors and will require institutional support to create the space for the intentional building of such relationships. Institutional support could include increasing the course credit for service-learning courses for students and 
providing advanced learning credits, assistantships, stipends, and research opportunities for peer mentors. In a similar way, institutions could offer reduced course loads, course assistants, and stipends to support professors.

Limitations of this study include a lack of focus on whether the community partner-student relationships positively impacted the community partners' missions. Further research is underway to address this important aspect of critical service-learning outcomes. Our small sample size of participants from one university in the Northeast likely lessens the generalizability of the findings to other higher education institutions. Additionally, students' engagement in different services throughout the local community may have impacted the mentoring relationships they developed and their overall experience. Varying levels of experience across classes, for both professors and SLAMs, may have also influenced the results. For example, faculty-community partner relationships were more long term for the students in the groups with SLAMs, which likely impacted the results. Further research is underway controlling for length and quality of faculty-community partner relationships to determine the impact on critical service-learning outcomes for all stakeholders.

Our findings suggest that critical outcomes are beginning to be realized in this pilot service-learning mentoring program, particularly as students plan to engage in civic action and report improved awareness of social justice and diversity. Differentiation among relationship and civic outcomes for SLAMs compared to professors and community partners suggest the importance of relationships in service-learning and a heightened need for a formal and ongoing training program for SLAMs. Although the themes that emerged from the focus groups support the reported CASQ and NRI findings of increased political, diversity, and social justice awareness and plans to engage in civic action in the future, longitudinal research is needed to determine if students who report more civic awareness engage in more civic action over time. Integrating information regarding students' mentoring needs and civic understanding would help those in higher education build more tailored and beneficial transformative service-learning programs.

The development of both civic action and social justice attitudes in service-learners demonstrates that building relationships with stakeholders in service-learning courses supports the development of these students as justice-oriented citizens (Mitchell, 2008; Westheimer \& Kahne, 2004). By expecting students and stakeholders of service-learning to engage in relationship building, institutions of higher education model for service-learning students how to be caring, justice oriented, and active citizens in their communities.

\section{References}

Baxter Magolda, M. B., \& Boes, L. M. (2017). Educational theory and student civic outcomes. In J. A. Hatcher, R. G. Bringle, \& T.W. Hahn (Eds.), Research on student civic outcomes in service learning: Conceptual frameworks and methods. Stylus Publishing.

Bernier, A., Larose, S., \& Soucy, N. (2005). Academic mentoring in college: The interactive role of student's and mentor's interpersonal dispositions. Research in Higher Education, 46(1), 29-51.

Boyle-Baise, M. (1999). "As good as it gets?” The impact of philosophical orientations on community-based service learning for multicultural education. Educational Forum, 63(4), 310-321. 
Brukardt, M. J., Holland, B., Percy, S. L., \& Zimpher, N., on behalf of Wingspread Conference Participants. (2004). Calling the question: Is higher education ready to commit to community engagement? The Milwaukee Idea, University of Wisconsin-Milwaukee.

Butin, D. W. (2010). Service-learning in theory and practice: The future of community engagement in higher education. Palgrave Macmillan.

Campbell, C. M., Smith, M., Dugan, J. P., \& Komives, S. R. (2012). Mentors and college student leadership outcomes: The importance of position and process. Review of Higher Education: Journal of the Association for the Study of Higher Education, 35(4), 595-625.

Campbell, J. L., Quincy, C., Osserman, J., \& Pedersen, O. K. (2013). Coding in-depth semi-structured interviews: Problems of unitization and intercoder reliability and agreement. Sociological Methods and Research, 42(3), 294-320.

Campus Compact. (2000). Presidents' declaration on the civic responsibility of higher education. Campus Compact.

Celio, C. I., Durlak, J., \& Dymnicki, A. (2011). A meta-analysis of the impact of service-learning on students. Journal of Experiential Education, 34(2), 164-181.

Cooper, J. R. (2014). Ten years in the trenches: Faculty perspectives on sustaining service-learning. Journal of Experiential Education, 37(4), 415-428.

Cross, B. E. (2005). New racism, reformed teacher education, and the same ole' oppression. Educational Studies, 38(3), 263-274.

DuBois, D. L., Portillo, N., Rhodes, J. E., Silverthorn, N., \& Valentine, J. C. (2011). How effective are mentoring programs for youth? A systematic assessment of the evidence. Psychological Science in the Public Interest, 12, 57-91.

Duncan, D., \& Kopperud, J. W. (2008). Service-learning companion. Houghton Mifflin.

Ehrlich, T. (Ed.). (2000). Civic responsibility and higher education. American Council on Education and Oryx Press.

Fassinger, R. E. (1997, August). Dangerous liaisons: Reflections on feminist mentoring. Invited "Women of the Year” award address presented at the annual meeting of American Psychology Association, Chicago, IL, United States.

Furman, W., \& Buhrmester, D. (1985). Children's perceptions of the personal relationships in their social networks. Developmental Psychology, 21(6), 1016-1024.

Haddock, S., Weiler, L. M., Krafchick, J., Zimmerman, T. S., McLure, M., \& Rudisill, S. (2013). Campus Corps therapeutic mentoring: Making a difference for mentors. Journal of Higher Education Outreach and Engagement, 17(4), 225-256.

Harkins, D. A. (Ed.). (2017). Alongside community: Learning in service. Routledge.

Harkins, D., Kozak, K., \& Ray, S. (2018). Service-learning: A case study of student outcomes. Journal of ServiceLearning in Higher Education, 8.

Hay, J. (1995). Transformational mentoring. McGraw-Hill. 
Hemer, K. M., \& Reason, R. D. (2017). Student civic outcomes in higher education. In J. A. Hatcher, R. G. Bringle, \& T. W. Hahn (Eds.), Research on student civic outcomes in service-learning: Conceptual frameworks and methods. Stylus Publishing.

Himley, M. (2004). Facing (up to) "the stranger" in community service learning. College Composition and Communication, 55(3), 416-438.

Hullender, R., Hinck, S., Wood-Nartker, J., Burton, T., \& Bowlby, S. (2015). Evidences of transformative learning in service-learning reflections. Journal of the Scholarship of Teaching and Learning, 15(4), 58-82.

Kegan, R. (2000). What "form" transforms? A constructive-developmental approach to transformative learning. In J. Mezirow (Ed.), Learning as transformation: Critical perspectives on a theory in progress (pp. 35-69). Jossey-Bass.

Landis, J. R., \& Koch, G. G. (1977). The measurement of observer agreement for categorical data. Biometrics, 33(1), 159-174.

Lunsford, L. G., Crisp, G., Dolan, E. L., \& Wuetherick, B. (2017). Mentoring in higher education. In D. A. Clutterbuck, F. Kochan, L. G. Lunsford, N. Dominguez, and J. Haddock-Millar(Eds.), The SAGE Handbook of Mentoring (pp. 318-334). Sage.

Mitchell, T. D. (2008). Traditional vs. critical service-learning: Engaging the literature to differentiate two models. Michigan Journal of Community Service Learning, 14(2), 50-65.

Moely, B. E., McFarland, M., Miron, D., Mercer, S., \& Ilustre, V. (2002). Changes in college students' attitudes and intentions for civic involvement as a function of service-learning experiences. Michigan Journal of Community Service Learning, 9, 18-26.

Moely, B. E., Mercer, S., Ilustre, V., Miron, D., \& McFarland, M. (2002). Psychometric properties and correlates of the civic attitudes and skills questionnaire (CASQ): A measure of students' attitudes related to servicelearning. Michigan Journal of Community Service Learning, 8, 15-26.

Musil, C. M. (2009). Educating students for personal and social responsibility: The civic learning spiral. In B. Jacoby (Ed.), Civic engagement in higher education: Concepts and practices (pp. 49-68). Jossey-Bass.

O’Meara, K., \& Niehaus, E. (2009). Service-learning is ... How faculty explain their practice. Michigan Journal of Community Service Learning, 16(1), 17-32.

Parks, S. D. (2000). Big questions, worthy dreams: Mentoring emerging adults in their search for meaning, purpose, and faith. Jossey-Bass.

Pascarella, E. T., \& Terenzini, P. T. (2005). How college affects students: A third decade of research (Vol. 2). Jossey-Bass.

Patton, M. Q. (2014). Qualitative research and evaluation methods (3rd ed.). Sage.

Rice, K., \& Pollack, S. (2000). Developing a critical pedagogy of service learning: Preparing self-reflective, culturally aware, and responsive community participants. In C. O'Grady (Ed.), Integrating service learning and multicultural education in colleges and universities (pp. 115-134). Lawrence Erlbaum Associates.

Robinson, E., \& Harkins, D. A. (2018). Lessons learned from faculty service-learning mentoring. Journal of Community Engagement and Higher Education, 10(3), 43-51. 
Rosenberg, P. M. (1997). Underground discourses: Exploring whiteness in teacher education. In M. Fine, L. Weis, L. C. Powell, L. M. Wong (Eds.), Off white: Readings on race, power, and society (pp. 79-89). Routledge. Rosenberger, C. (2000). Beyond empathy: Developing critical consciousness through service learning. In C. R. O'Grady (Ed.), Integrating service learning and multicultural education in colleges and universities (pp. 2343). Lawrence Erlbaum Associates.

Saltmarsh, J., \& Harley, M. (2008, February 26-27). Framing Statement. Invitational Colloquium, Kettering Foundation, Dayton, OH, United States.

Sleeter, C. E. (2001). Preparing teachers for culturally diverse schools: Research and the overwhelming presence of whiteness. Journal of Teacher Education, 52(2), 94-106.

Sullivan, H. S. (1953). The interpersonal theory of psychiatry. Norton.

Syed, M., \& Nelson, S. C. (2015). Guidelines for establishing reliability when coding narrative data. Emerging Adulthood, 3(6), 375-387.

Torney-Purta, J., Cabrera, J. C., Roohr, K. C., Liu, O. L., \& Rios, J. A. (2015). Assessing civic competency and engagement in higher education: Research background, frameworks, and directions for next-generation assessment. ETS Research Report Services, 2015(2), 1-48.

Varlotta, L. E. (1997). A critique of service-learning's definitions, continuums, and paradigms: A move towards a discourse-praxis community. Educational Foundations, 11(3), 53-85.

Weiler, L., Haddock, S., Zimmerman, T. S., Krafchick, J., Henry, K., \& Rudisill, S. (2013). Benefits derived by college students from mentoring at-risk youth in a service-learning course. American Journal of Community Psychology, 52(3-4), 236-248.

Weiss, R. S. (1974). The provisions of social relationships. In Z. Rubin (Ed.), Doing unto others: Joining, molding, conforming, helping, loving (pp. 17-26). Prentice-Hall.

Westheimer, J., \& Kahne, J. (2004). What kind of citizen? The politics of educating for democracy. American Educational Research Journal, 41(2), 237-269.

Wu, J.-Y., \& Hughes, J. N. (2015). Teacher Network of Relationships Inventory: Measurement invariance of academically at-risk students across ages 6 to 15. School Psychology Quarterly, 30(1), 23-36.

Yorio, P. L., \& Feifei, Y. (2012). A meta-analysis on the effects of service-learning on the social, personal, and cognitive outcomes of learning. Academy of Management Learning and Education, 11(1), 9-27.

\section{Authors}

DEBRA A. HARKINS, PhD, is Professor of Psychology at Suffolk University, Boston. Dr. Harkins specializes in community engagement, service-learning, and multi-tiered mentoring and has been teaching a servicelearning course, Community Psychology, every semester for more than 15 years.

LAUREN I. GRENIER, MA, is a 4th-year clinical doctoral student in psychology at Suffolk University, Boston. Ms. Grenier specializes in service-learning and mentoring and has been co-piloting a service-learning course, Socially Responsible Leadership, for two years. 
CYNTHIA IRIZARRY, PhD, is Associate Professor of Communication and Journalism at Suffolk University, Boston. Dr. Irizarry specializes in organizational communication, public relations, and health communication and teaches a service-learning oriented course in Public Relations.

ELIZABETH ROBINSON, EdD, is Assistant Professor of Education at Suffolk University, Boston. Dr. Robinson specializes in English as second language and teacher and urban education and teaches the service-learning courses Introduction in Teaching and Community Tutoring.

SUKANYA RAY, PhD, is Associate Professor of Psychology at Suffolk University, Boston. Dr. Ray specializes in ethnic minority health disparities, Asian mental health, and resiliency and teaches experiential learning courses, including Asian Psychology.

LYNNE-MARIE SHEA, MA, is a 3rd-year clinical doctoral student in psychology at Suffolk University, Boston. Ms. Shea specializes in community engagement and humility and has been co-piloting a service-learning course, Socially Responsible Leadership. 